\title{
Effects of Antihistamines on 3,4-Methylenedioxymethamphetamine-Induced Depletion of Serotonin in Rats
}

\author{
S.Y. YEH, ${ }^{1 *}$ C. DERSCH, ${ }^{2}$ R. ROTHMAN, ${ }^{2}$ AND J .L. CADET ${ }^{1}$ \\ ${ }_{1}^{1}$ Mol ecular Neuropsychiatry Section, National I nstitute on Drug Abuse, I ntramural Research Program, \\ National Institute of Health, Baltimore, Maryland \\ ${ }^{2}$ Clinical Psychopharmacology Section, National Institute on Drug Abuse, Intramural Research Program, \\ National Institute of Health, Baltimore, Maryland
}

KEY WORDS MDMA; neurotoxicity; hyperthermia; antihistamine; chlorpheniramine; diphenhydramine; tripelennamine; pyrilamine

\begin{abstract}
This study investigated the effects of chlorpheniramine (CPA, 10-25 $\mathrm{mg} / \mathrm{kg}$ ), diphenhydramine (DIPH, $20 \mathrm{mg} / \mathrm{kg}$ ), tripelennamine (TRIP, $20 \mathrm{mg} / \mathrm{kg}$ ), and pyrilamine (PYRI, $20 \mathrm{mg} / \mathrm{kg}$ ) on 3,4-methylenedioxymethamphetamine (MDMA, 20 $\mathrm{mg} / \mathrm{kg} \times 2$ )-induced hyperthermia and depletion of indoles in rat brains, on the uptake of serotonin and dopamine into rat synaptosomes, on the binding affinity of CPA for biogenic amine transporters in the synaptosomes of rat brain, and on thescavenging hydroxyl free radicals activity. Rats were treated with two injections of MDMA, CPA, DIPH, TRIP, PYRI, and saline, al one or in combination of MDMA with one of the antihistamines, $6 \mathrm{~h}$ apart and sacrificed 5 days later. Rectal temperature was measured prior to and hourly following the drug injections for $13 \mathrm{~h}$. As compared to saline controls, MDM A increased body temperature and decreased levels of indoles, measured by HPLC, in several brain regions of rats. CPA attenuated and DIPH had no effect on MDMA-induced hyperthermia, yet both attenuated the depletion of indoles, whereas PYRI and TRIP potentiated these effects. CPA inhibited the binding of $\left[{ }^{3} \mathrm{H}\right]$ paroxetine and $\left[{ }^{3} \mathrm{H}\right]$ nisoxetine to the synaptosomes of cerebral cortex and of $\left[{ }^{3} \mathrm{H}\right]$ win 35,428 to the synaptosomes of striatum. CPA, DIPH, TRIP, and PYRI inhibited [ $\left.{ }^{3} \mathrm{H}\right]$ serotonin uptake. CPA, PYRI, and TRIP, but not DIPH, scavenge hydroxyl radicals. Possible mechanisms of the different effects of the antihistamines on MDMA-induced hyperthermia and depletion of serotonin are discussed. Synapse 33:207-217, 1999. Published 1999 Wiley-Liss, Inc. ${ }^{\dagger}$
\end{abstract}

\section{INTRODUCTION}

3,4-Methylenedi oxymethamphetamine (MDMA), an amphetamine analog, is well known as a drug of abuse in both the U.S. and Europe and is a neurotoxin. The neurotoxic effects of MDMA have been shown to cause a decrease of serotonin (5-HT) and its metabolite, 5-hydroxyindole-3-acetic acid (5-HIAA), of 5-HT transporter and in tryptophan hydroxylase activity in several brain regions of rodents and nonhuman primates (Battaglia et al., 1987; Commins et al., 1987; Insel et al., 1989; Schmidt, 1987; Stone et al., 1986). These MDMAinduced deleterious effects are associated with hyperthermia in both rodents and humans at ambient temperatures above $23^{\circ} \mathrm{C}$ (Nash et al., 1988; Henry et al., 1992). The hyperthermia induced by MDMA in rodents is potentiated in a hyperthermic environment and is attenuated both in a hypothermic environment and by drugs that attenuate MDMA-induced hyperthermia
(Miller and O'Callaghan, 1994; Farfel and Seiden, 1995; Malberg et al., 1996).

The neurotoxicity of MDMA has been attributed to its metabolites, 2,3,4-trihydroxymethamphetamine (TriOH-MDMA; Elayan et al ., 1993) or 3,4-dihydroxymethamphetamine quinone (Hiramatsu et al., 1990). F ormation of these metabolites of MDMA involves cytochrome P-450 enzymes (Hiramatsu et al., 1990). It is hypothesized that inhibition of P-450 enzymatic activity may attenuate the neurotoxicity of MDMA. Antihistamine blockers such as chl orpheniramine (CPA), diphenhydramine (DIPH), and pyrilamine (PYRI) have been shown to bind to cytochrome P-450 enzymes and to inhibit cytochrome P-450 hydroxylase activity (Hiroi et al.,

\footnotetext{
Preliminary results appeared in Neuroscience Abstracts, 1997 27:2141(831.8) *Correspondence to: S.Y. Yeh, Ph.D., Addiction Research Center, NIDA/NIH, P.O. Box 5180, Baltimore, MD 21224.

Received 7 October 1998; Accepted 30 November 1998
} 
1995). In addition, CPA inhibits 5-HT uptake (Carlsson and Lindqvist, 1969) and attenuates p-chloroamphetamine (PCA)-induced depletion of 5-HT (Fuller et al., 1975).

In view of these earlier reports, the present studies were undertaken to examine the effects of the antihistamines on MDMA-induced hyperthermia, depletion of 5-HT and 5-HIAA in the brain of rats, the uptake of serotonin and dopamine into rat synaptosomes, the binding affinity of CPA for biogenic amine transporters in the synaptosomes of rat brain, and scavenging of hydroxyl radicals.

\section{MATERIALS AND METHODS Animals and housing}

Male Sprague-Dawl ey rats (250-275 g, Harlan Industries, Indianapolis, I N) were housed, three per polycarbonate cage bedded on chipped corn cobs, in an airconditioned room $\left(22 \pm 1^{\circ} \mathrm{C}\right)$ with $12 / 12 \mathrm{~h}$ light-dark cycles (lights on 7:00 to 19:00). Rats had free access to Purina chow and water and were allowed at least a 1-week adjustment period before being used for an experiment. Animals used in this study were maintained in facilities accredited by the Association for the Accreditation of Laboratory Animal Careand theexperiments were conducted in accordance with the Guidefor Care and Use of Laboratory Animals provided by the $\mathrm{NIH}$ and adopted by the NIDA.

\section{Dose regimen}

Based on results obtained from a preliminary study (see below), the following dose regime was selected. (Doses of drugs used in this study are expressed as free base.) In the first series of experiments, MDMA (20 $\mathrm{mg} / \mathrm{kg}$ ) was administered s.c., $6 \mathrm{~h}$ apart to produce the neurotoxic effects. In the second series of experiments, MDMA (20 mg/kg) was administered s.c., twice, $7 \mathrm{~h}$ apart in order to study the timing effect of CPA, which was injected at $6 \mathrm{~h}$ after MDMA. CPA (10 or 20 and 25 $\mathrm{mg} / \mathrm{kg}$ ), or DIPH $(20 \mathrm{mg} / \mathrm{kg})$, tripelennamine (TRIP, 20 $\mathrm{mg} / \mathrm{kg}$ ), PYRI (20 mg/kg), and saline (2 ml/kg) was i.p. injected al one or in combination with MDMA, twice, $6 \mathrm{~h}$ (first series of experiments) or $7 \mathrm{~h}$ (second series of experiments) apart. Saline was used as the control, both al one or co-injection with MDMA or the antihistamines. The doses of CPA (10, 20, and $25 \mathrm{mg} / \mathrm{kg}$ ) for the present study were chosen from the literature (Carlsson and Lindqvist, 1969), the results of interactions of MDMA and CPA (see below), and after determining that a $5 \mathrm{mg} / \mathrm{kg}$ dose of CPA did not attenuate fenfluramine-induced depletion of 5-HT (Yeh, 1999b). The doses of DIPH, TRIP, and PYRI are based on that of CPA.

\section{Temperature experiments}

In the first series of experiments, rats were transferred to an air-conditioned room $\left(22 \pm 0.5^{\circ} \mathrm{C}\right)$, weighed, and housed individually in hanging metal wire mesh cages $(25 \times 20 \times 18 \mathrm{~cm})$, and provided with chow and water ad libitum for at least $1 \mathrm{~h}$ before temperature measurement. Rectal temperature was measured with a thermal probe connected to a digital readout (Yellow Spring Co., Columbus, $\mathrm{OH}$ ) prior to and then hourly following drug injection for $5 \mathrm{~h}$, as described previously (Yeh, 1997a). MDM A (20 mg/kg, s.c.) and CPA (10 or 25 $\mathrm{mg} / \mathrm{kg}$, i.p.) were administered either separately or MDMA plus CPA were administered concurrently. The animals were returned to the animal quarters and housed in groups of three after the second drug injection (6 $\mathrm{h}$ after the first injection).

In the second series of experiments, rectal temperature was measured as mentioned above except that the rats were housed three per polycarbonate cage bedded on chipped corn cobs during the experimental period. Following the initial temperaturemeasurement, MDMA $(20 \mathrm{mg} / \mathrm{kg}$, s.C.), CPA, DI PH, TRIP, and PYRI $(20 \mathrm{mg} / \mathrm{kg}$, i.p.) and saline were injected at 0 and $7 \mathrm{~h}$. Other animals were injected concurrently with MDMA plus either CPA, DIPH, TRIP, and PYRI, or saline at 0 and 7 h. In addition, CPA was injected 3 or $6 \mathrm{~h}$ after MDMA alone, to examine if CPA attenuated either the MDMAinduced depletion of 5-HT or its hyperthermic effects. This was done with a view toward clinical treatment of MDMA intoxication. It was necessary to inject the second dose of drug at $7 \mathrm{~h}$ to study the timing effect of CPA, which was injected at $6 \mathrm{~h}$ after MDMA. Control rats were injected with saline. The animals were returned to the animal quarters $14 \mathrm{~h}$ after the first drug injection. Six rats were used in the beginning for each treatment group in the first and second series of experiments.

\section{Neurochemical experiments}

Based on the results obtained in a previous study (Yeh, 1998), the rats were sacrificed by decapitation 5 days following the last drug injection. Brains were removed rapidly. Brain regions were dissected over ice according to the method of Glowinski and Iversen (1966), frozen immediately in liquid nitrogen, and stored at $-75^{\circ} \mathrm{C}$ until the monoamines and their metabolites were measured by high performanceliquid chromatography (HPLC) as described previously (Yeh, 1997a).

\section{Measurement of uptake of $\left[{ }^{3} \mathrm{H}\right]$-serotonin and [ $\left.{ }^{3} \mathrm{H}\right]$-dopamine and transporters binding}

Experiments determining the uptake of $\left[{ }^{3} \mathrm{H}\right]$-serotonin and $\left[{ }^{3} \mathrm{H}\right]$-dopamine were performed as previously described, with the modification that $\left[{ }^{3} \mathrm{H}\right]$-serotonin uptake was performed on cerebral cortex (Rothman et al., 1993). Uptake of $\left[{ }^{3} \mathrm{H}\right]-\mathrm{NE}$ was not measured be cause CPA did not affect $\left[{ }^{3} \mathrm{H}\right]$-nisoxetine binding to the synaptosomes of cerebral cortex and treatment of MDMA and antihistamines alone or in combination did not alter the content of NE. 
Receptor ligand binding of transporters of serotonin, norepinephrine, and dopamine were performed as described previously (Boja et al., 1995). K $\mathrm{K}_{\mathrm{i}}$ values were calculated from the radioligand binding analysis programs (McPherson, 1988). Proteins were determined according to the method of Lowry et al. (1951).

\section{Measurement of scavenging of hydroxyl radical activity}

Scavenging of hydroxyl radicals activity of antihistamines was measured by the method of Rehman et al. (1997). In brief, hydroxyl radicals were generated by a mixture containing deoxyribose $(2.8 \mathrm{mM}), \mathrm{KH}_{2} \mathrm{PO}_{4}^{-}$ $\mathrm{KOH}$ buffer, pH $7.4(10 \mathrm{mM}), \mathrm{FeCl}_{3}(25 \mu \mathrm{M}), \mathrm{EDTA}(100$ $\mu \mathrm{M}), \mathrm{H}_{2} \mathrm{O}_{2}(2.8 \mathrm{mM})$, and ascorbic acid $(100 \mu \mathrm{M})$. After incubation at $37^{\circ} \mathrm{C}$ for $60 \mathrm{~min}, 1 \mathrm{ml}$ each of $2.8 \%$ of trichloroacetic acid and $1 \%(\mathrm{w} / \mathrm{v})$ of thiobarbituric acid in $50 \mathrm{mM}$ of $\mathrm{NAOH}$ was added to the mixture. The mixture was heated at $100^{\circ} \mathrm{C}$ for $20 \mathrm{~min}$. The absorbance of the colored solution measured at $532 \mathrm{~nm}$ was taken as the amount of hydroxyl radicals (100\%) generated by the system. Decrease in absorbance of a solution of the system containing an antihistamine was taken as scavenging of hydroxyl radical activity by the antihistamine. A proper control containing various concentrations of maleic acid was included for measurement of the scavenging of hydroxyl radicals by CPA maleate and PYRI maleate.

\section{Data analysis}

The overall significance of the data on the content of monoamines in various brain regions was assessed by a two-way ANOVA with the software BMDP program 7D and the data of body temperature was assessed by BMDP program 2V and 7D (Dixon et al., 1990). When the $F$ and $P$ values were significantly different between the treatment groups, a post-hoc comparison, with Bonferroni test, was used to assess differences between the individual pairs of means. Criteria for significance were set at the $\mathrm{P} \leq 0.05$ level.

\section{Drugs}

d,1-3,4-Methylenedioxymethamphetamine $\mathrm{HCl}$ was provided by Research Triangle Institute (Research Triangle Park, NC) through an arrangement with NIDA (Rockville, MD). d,1-Chlorpheniraminemaleate, diphenhydramine $\mathrm{HCl}$, tripel ennamine $\mathrm{HCl}$, pyrilamine maleate, sodium heptane sulfonate, perchloric acid, citric acid, sodium acetate, and acetonitrile were purchased from Sigma Chemical Co. (St. Louis, MO).

\section{RESULTS}

\section{Effects of MDMA dose regimen on serotonin levels in the brain}

The effects of MDMA dose on neurotoxicity and the effect of CPA dose on MDMA-induced neurotoxicity
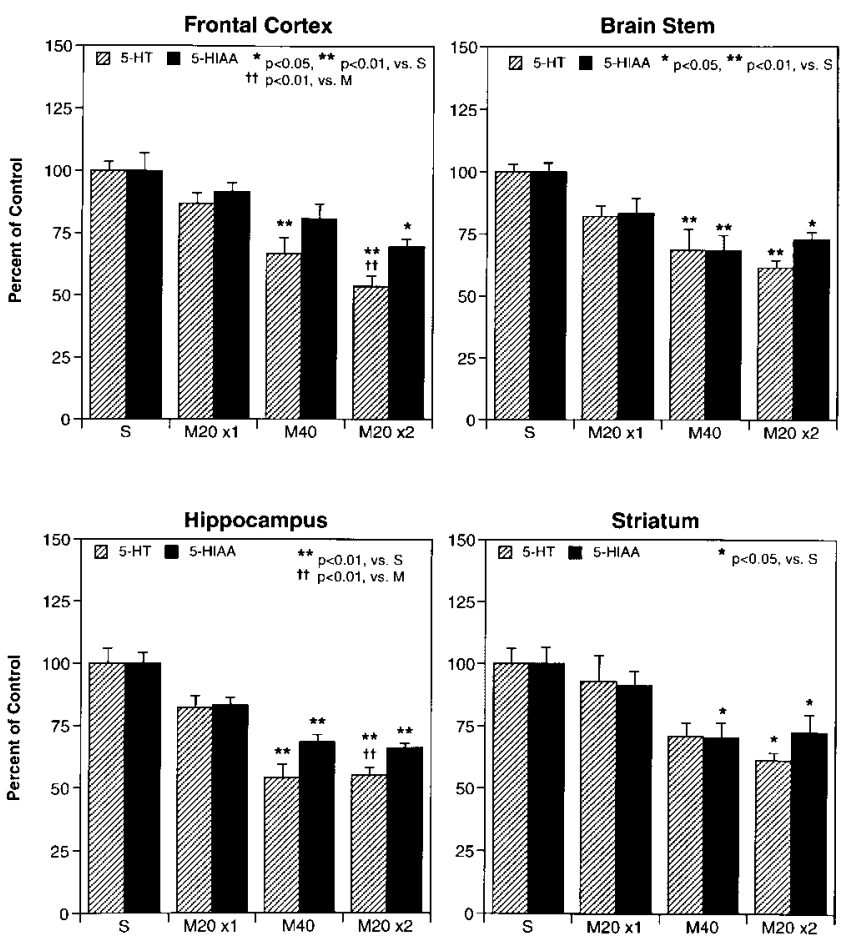

Fig. 1. Effects of MDMA dose regimen ( 20 or $40 \mathrm{mg} / \mathrm{kg}$ s.c., once, or $20 \mathrm{mg} / \mathrm{kg}$, s.c., twice, $6 \mathrm{~h}$ apart) on serotonin levels in the frontal cortex, hippocampus, brain stem, and striatum. Levels of 5-HT and 5 -HIAA (pg/mg wet tissue, mean \pm SE M) of saline-treated rats in the frontal cortex were $516 \pm 26$ and $287 \pm 13$, respectively; in the hippocampus $360 \pm 10$ and $413 \pm 13$, respectively $(n=6)$. $* P \leq 0.05$, $* * \mathrm{P} \leq 0.01$ vs. saline.

were studied prior to the current investigation (Yeh, 1997b). The results showed that both a single dose of 40 $\mathrm{mg} / \mathrm{kg}$ of MDMA (Fig. 1) or a dose of $20 \mathrm{mg} / \mathrm{kg}$ of MDMA given twice $6 \mathrm{~h}$ apart significantly depleted levels of 5-HT and 5-HIAA (50-60\% of saline controls) in the frontal cortex, hippocampus, brain stem, and striatum compared to sal ine controls (Fig. 1). A single dose of 20 $\mathrm{mg} / \mathrm{kg}$ of MDMA decreased serotonin about $15 \%$ in these regions, not significantly different from that of controls (Yeh, 1997a). A dose of $20 \mathrm{mg} / \mathrm{kg}$ of MDMA given twice, $6 \mathrm{~h}$ apart, was chosen in the present study in view of the $L_{50}, 49 \mathrm{mg} / \mathrm{kg}$, of MDMA (Hardman et al., 1973). A dose of CPA at 10 or $25 \mathrm{mg} / \mathrm{kg}$ blocked the MDMA-induced depletion of serotonin (Yeh, 1997b).

\section{Effect of CPA on MDMA-induced depletion of 5-HT and 5-HIAA}

In the first series of experiments, concurrent injections of MDMA plus saline significantly decreased levels of 5-HT and 5HIAA (53-61\% of saline controls) in the frontal cortex, hippocampus, brain stem, and striatum ( $\mathrm{P}<0.01)$ (Fig. 2). MDMA-induced depletion of 5-HT and 5-HIAA in the frontal cortex, hippocampus, brain stem, and striatum was completely blocked by 10 or $25 \mathrm{mg} / \mathrm{kg}$ of CPA (i.p.) administered concurrently (Fig. 2). In comparison to controls, 5-HT levels were 


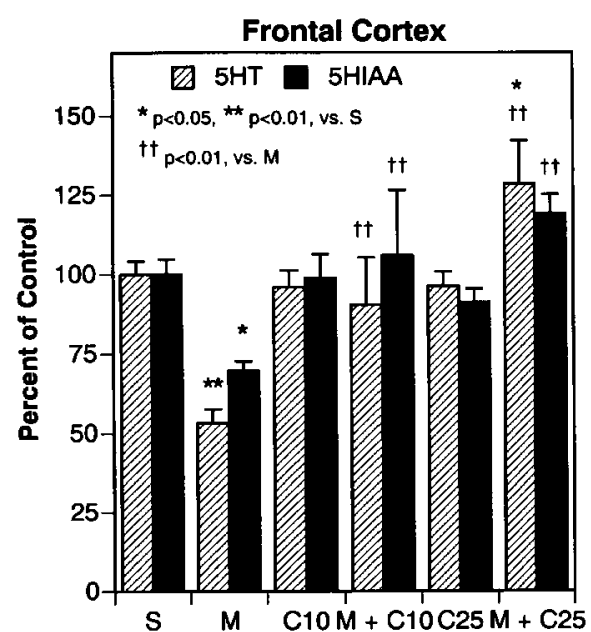

S $\quad \mathrm{M} \mathrm{C} \quad \mathrm{M} M+\mathrm{C} 10 \mathrm{C} 25 \mathrm{M}+\mathrm{C} 25$

Hippocampus

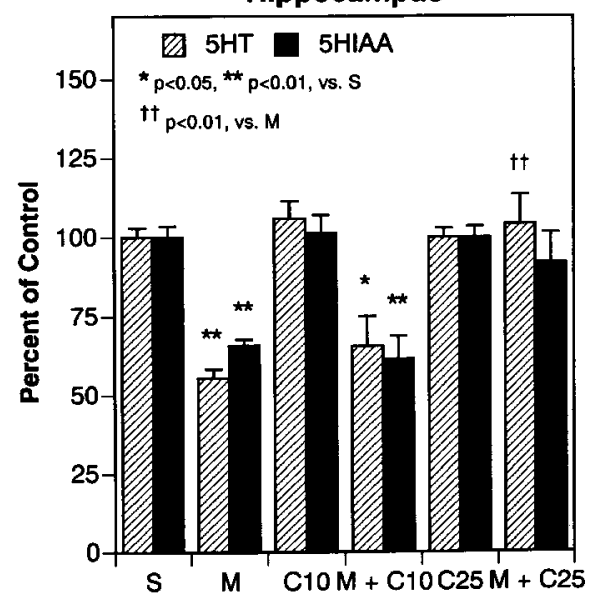

Brain Stem

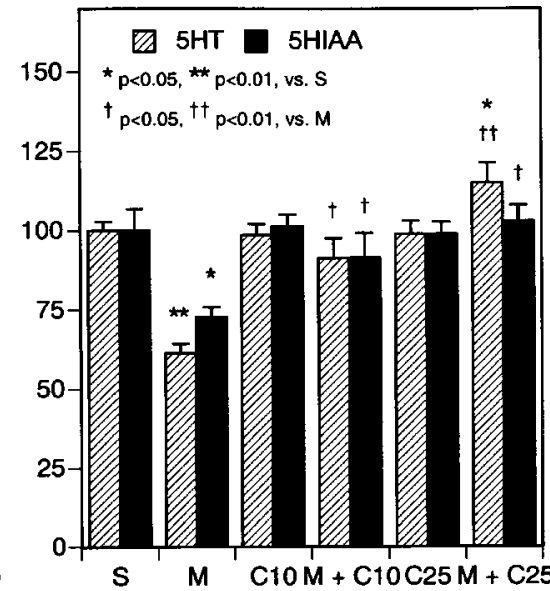

Striatum

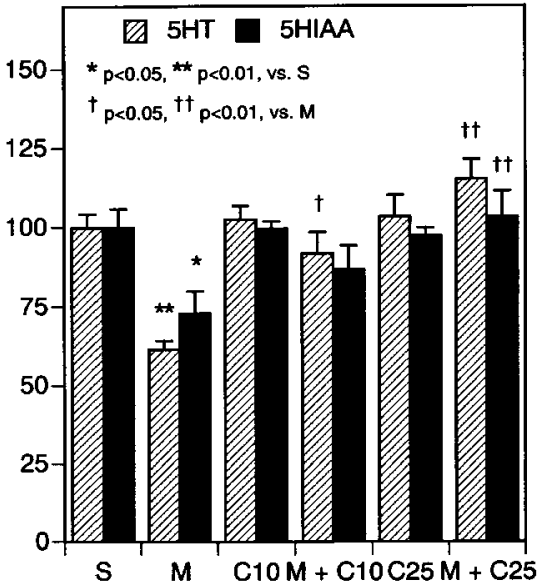

Fig. 2. Effects of CPA dose (C10 or C25 $\mathrm{mg} / \mathrm{kg}$, i.p.) on MDMA (20 mg/kg, s.c. twice, 6 $\mathrm{h}$ apart)-induced depletion of serotonin in the frontal cortex, hippocampus, brain stem, and striatum. Levels of 5-HT and 5-HIAA (pg/mg wet tissue, mean \pm SEM) of saline-treated rats in the frontal cortex were $516 \pm 26$ and $287 \pm 13$, respectively; in the hippocampus $360 \pm 10$ and $413 \pm 13$, respectively; in the brain stem, $744 \pm 22$ and $744 \pm 51$, respectively; and in the striatum $441 \pm 19$ and 570 \pm 22 , respectively $(\mathrm{n}=6)$. $* \mathrm{P} \leq 0.05, * * \mathrm{P} \leq$ 0.01 vs. saline; $++P \leq 0.01, M+C$ vs. $M+S$. significantly higher in the frontal cortex and brain stem of rats treated with MDMA plus $25 \mathrm{mg} / \mathrm{kg}$ dose of CPA (Fig. 2). The levels of 5-HT in the frontal cortex and hippocampus of rats treated with MDMA plus $25 \mathrm{mg} / \mathrm{kg}$ of CPA were significantly higher than those treated with MDMA plus 10 mg/kg CPA (symbols not shown in the graph). There were no significant differences be tween saline-, CPA- (10 or $25 \mathrm{mg} / \mathrm{kg}$ ), and MDMA plus CPA (10 mg/kg)-treated rats, except for a significantly Iower value in the hippocampus of rats treated with MDMA plus $10 \mathrm{mg} / \mathrm{kg}$ of CPA (Fig. 1).

\section{Time course effects of chlorpheniramine on MDMA-induced depletion of 5-HT and 5-HIAA}

The levels of 5-HT and 5-HIAA in the frontal cortex, hippocampus, brain stem, and striatum of rats treated with MDMA, obtained from the second series of experiments, were significantly decreased, similar to the results obtained in the first series of experiments (Fig. 3). MDMA-induced depletion of 5-HT and 5-HIAA in these brain regions was completely blocked by CPA administered either concurrently or 3 and $6 \mathrm{~h}$ after
MDMA (Fig. 2). There were no significant differences between saline and CPA-treated animals.

\section{E ffect of diphenhydramine on MDMA-induced depletion of 5-HT and 5-HIAA}

MDMA-induced depletion of 5-HT and 5-HIAA in the frontal cortex, hippocampus, brain stem, and striatum was completely blocked by DIPH administered concurrently (Fig. 4). There were no significant differences between saline and DIPH-treated animals.

\section{E ffect of tripelennamine on MDMA-induced depletion of 5-HT and 5-HIAA}

Treatment of MDMA plus TRIP produced variable levels of 5 -HT and 5 -HIAA. In three of the four surviving rats (two died apparently from hyperthermia and the survival of the four rats appears to be due to biologic variation via absorption and metabolism of drugs), the mean levels of 5-HT and 5-HIAA in the frontal cortex were $90.01 \pm 4.75$ and $101.66 \pm 5.08 \%$ of saline control, respectively, whereas in one rat with hyperthermia, the 

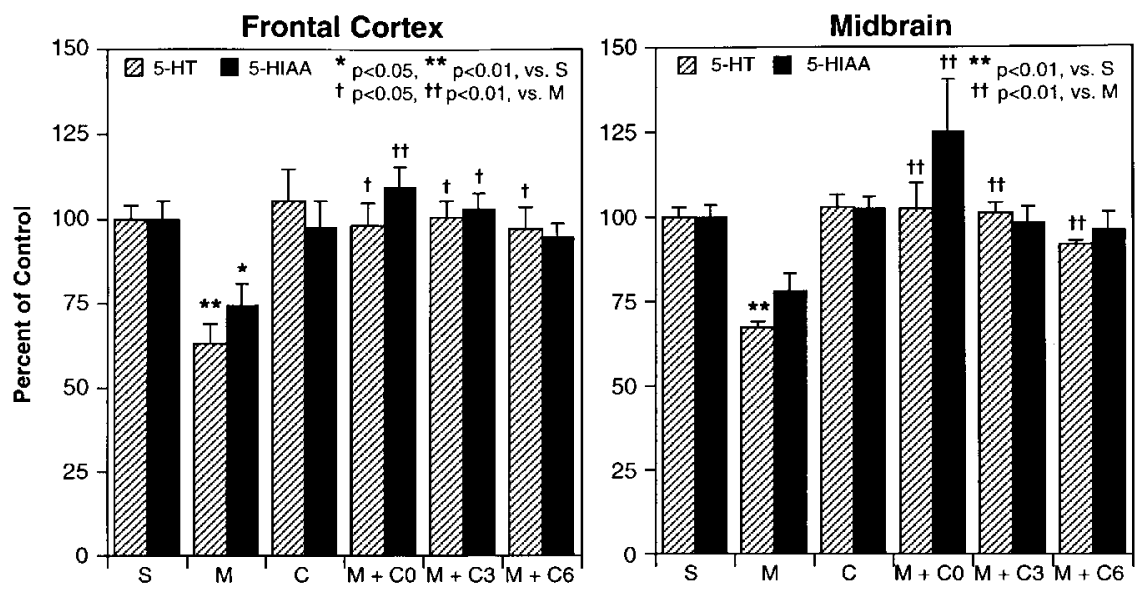

Fig. 3. Time course effects of CPA $(20$ $\mathrm{mg} / \mathrm{kg}$, i.p. administered concurrently (CO) or 3 (C3) and 6 (C6) h after MDMA) on MDMA (20 mg/kg, i.p. twice, $7 \mathrm{~h}$ apart)-induced depletion of serotonin in the frontal cortex (upper panel) and hippocampus (lower panel). Levels of 5-HT and 5-HIAA of saline-treated rats in the frontal cortex were $642 \pm 27$ and $470 \pm 26$ $(\mathrm{pg} / \mathrm{mg}$ wet tissue, mean $\pm \mathrm{SEM})$, respectively $(n=6)$. ${ }^{* * P} \leq 0.01$ vs. saline; $+P \leq$ $0.05,++P \leq 0.01, M+C$ vs. $M+S$.
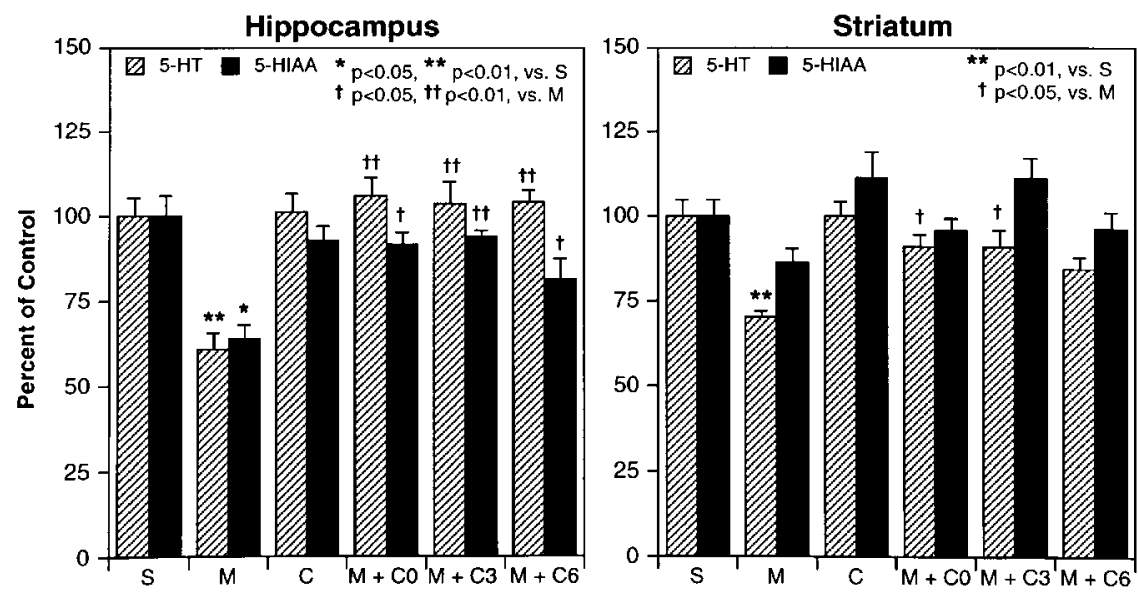

respective values were 21.18 and $27.62 \%$ of saline control. The overall results $(n=4)$ of levels of $5-\mathrm{HT}$ and 5-HIAA in the frontal cortex, brain stem, and striatum were not significantly different from that of the saline group (Fig. 4). The level of 5-HT and 5-HIAA in the hippocampus of rats treated with MDMA plus TRIP decreased significantly (Fig. 4). There were no significant differences between saline- and TRIP-treated animals.

\section{Effect of pyrilamine on MDMA-induced depletion of 5-HT and 5-HIAA}

The levels of 5-HT and 5-HIAA in the frontal cortex, hippocampus, brain stem, and striatum of the two surviving rats (four died apparently from hyperthermia and those that survived possibly due to biologic variation via absorption and metabolism of drugs) treated with MDMA plus PYRI were decreased significantly from both those of the saline controls (about 40\%) and those of the MDMA plus saline treatment group (Fig. 3). There were no significant differences between saline- and PYRI-treated animals.

The levels of NE in the frontal cortex, hippocampus, brain stem, and striatum of rats treated with MDMA,
CPA, DIPH, TRIP, and PYRI al one and in combination of MDMA with one of the antihistamines were not significantly different from that of saline control (data not shown).

\section{Effects of antihistamines on the uptake of [ $\left.{ }^{3} \mathrm{H}\right] 5-\mathrm{HT}$ and $\left[{ }^{3} \mathrm{H}\right]$-dopamine, ligand binding to 5-HT, DA, and NE transporters in the brain tissue}

The $K_{i}$ values of $C P A$ on the binding of $\left[{ }^{3} \mathrm{H}\right]$ paroxetine to the presynaptic $5-\mathrm{HT}$ transporters, of $\left[{ }^{3} \mathrm{H}\right] \mathrm{Win} 35,428$ to the DA transporters, and of $\left[{ }^{3} \mathrm{H}\right]$ ni soxetine to the NE transporters were 30.6, 973, and 4,275 nM, respectively. CPA, TRIP, and PYRI were potent inhibitors of the uptake of $\left[{ }^{3} \mathrm{H}\right] 5-\mathrm{HT}$ into synaptosomes of cerebral cortex, with $\mathrm{IC}_{50}$ values of 89,90 , and $141 \mathrm{nM}$, respectively (Table I). DIPH did not inhibit the uptake of $\left[{ }^{3} \mathrm{H}\right] 5-\mathrm{HT}$ into synaptosomes of cerebral cortex, with an ${ }^{\prime} C_{50}$ value of 11,095 nM (Table I). TRIP was a strong inhibitor, whereas CPA, DIPH, and PYRI had a moderate effect on the uptake of [ $\left.{ }^{3} \mathrm{H}\right]$-dopamine into synaptosomes of striatum, with I $C_{50}$ values of $214,1,157,3,042$, and 2,935 nM, respectively. 

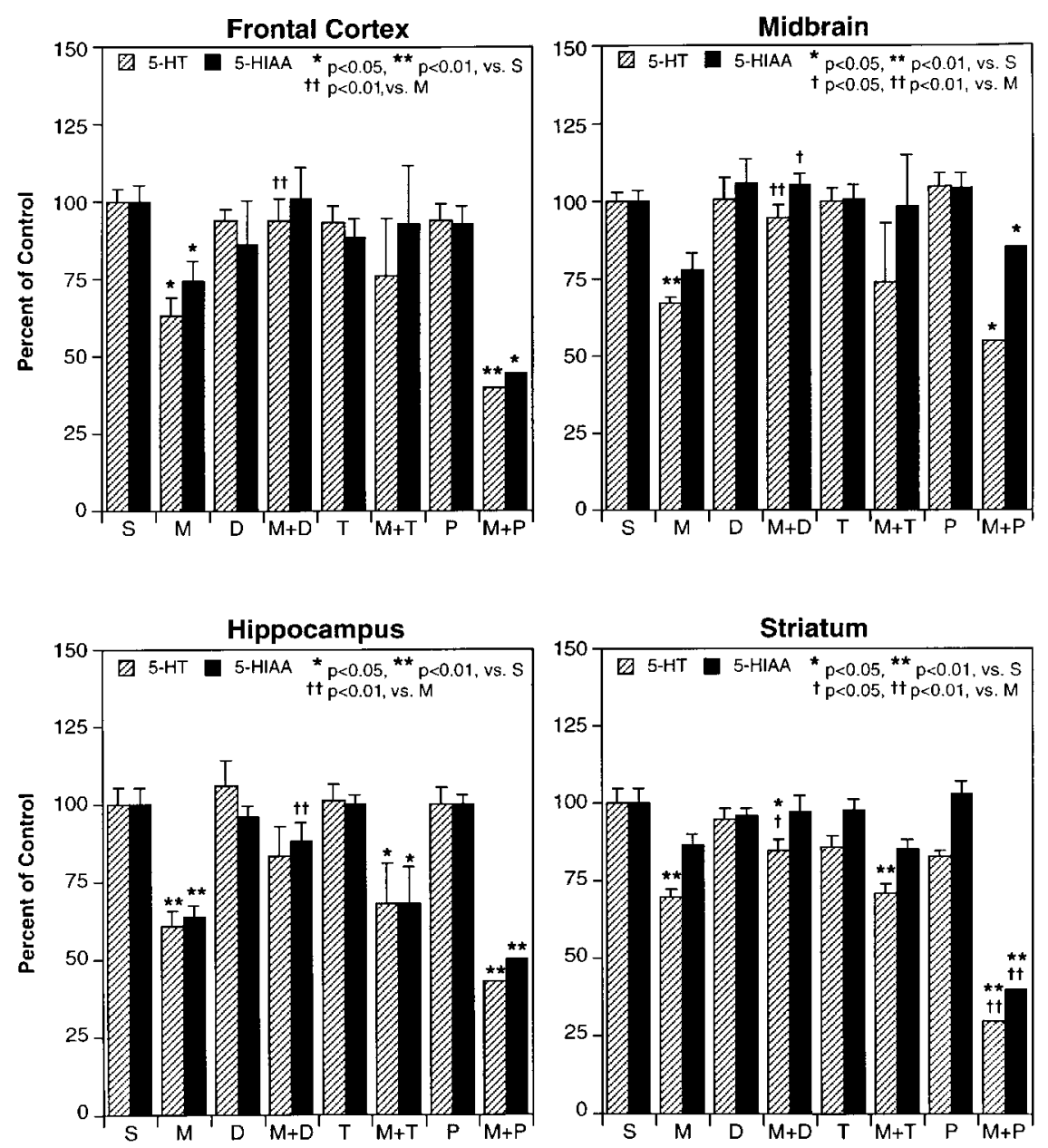

Fig. 4. Effects of DIPH (D), TRIP (T), and PYRI (P) (20 mg/ $/ \mathrm{kg}$, i.p.) on MDMA ( $20 \mathrm{mg} / \mathrm{kg}$, S.c., twice, $7 \mathrm{~h}$ apart)-induced depletion of serotonin in the frontal cortex (upper panel) and hippocampus (lower panel). Treatment of animals and levels of 5HT and 5-HIAA levels in the frontal cortex and hippocampus of saline control rats are stated in the legend of Figure 1. Number of rats in $\mathrm{M}$ treatment group is 6; in M + CPA group 5; in M + DIPH group 5; in M + TRIP group 4; and in M + PYRI group 2. $* \mathrm{P} \leq 0.05,{ }^{*} * \mathrm{P} \leq 0.01$ vs. saline; $+\mathrm{P} \leq 0.05,++\mathrm{P} 0.01, \mathrm{M}+$ antihistaminevs. $\mathrm{M}+\mathrm{S}$.

TABLE I. Effects of antihistamines on uptake of $\left[{ }^{3} \mathrm{H}\right]$-serotonin in the synaptosomes of cerebral cortex and of [ $\left.{ }^{3} \mathrm{H}\right]$-dopaminein thestriatum of rats

\begin{tabular}{lcc}
\hline & \multicolumn{2}{c}{$\mathrm{IC}_{50}(\mathrm{nM}$, Mean $\pm \mathrm{SD})$} \\
\cline { 2 - 3 } Antihistamine & $\begin{array}{c}\text { Uptake of } \\
{\left[{ }^{3} \mathrm{H}\right] \text {-serotonin }}\end{array}$ & $\begin{array}{c}\text { Uptake of } \\
{\left[{ }^{3} \mathrm{H}\right] \text {-dopamine }}\end{array}$ \\
\hline Chlorpheniramine & $88.7 \pm 4.8$ & $1,157 \pm 71$ \\
Diphenhydramine & $11,095 \pm 4.06$ & $3,042 \pm 124$ \\
Tripelennamine & $89.6 \pm 14$ & $214 \pm 9$ \\
Pyrilamine & $141 \pm 17$ & $2,935 \pm 192$ \\
\hline
\end{tabular}

Data were obtained from three experiments in triplicate for each experiment.

\section{Effects of antihistamines on the scavenging of hydroxyl radicals}

CPA and PYRI were potent hydroxyl radicals scavengers, whereas TRIP had a moderate effect and DIPH had no effect on scavenging of hydroxyl radicals (Tablell).

\section{Effects of MDMA and CPA on body temperature}

Results from the first experiment indicated that there was a significant effect on body temperature of rats following treatment with MDMA, CPA (10 and 25 $\mathrm{mg} / \mathrm{kg})$, and saline al one or in combination $[\mathrm{F}(5,47)=$ 37.32, $\mathrm{P}<0.00001$ ]. Rectal temperature of rats increased significantly from 2-5 h postinjection of 20 $\mathrm{mg} / \mathrm{kg}$ of MDM A as compared with sal ine controls ( $\mathrm{P}<$ 0.01 ). In contrast, temperature decreased significantly after MDMA plus CPA (10 or $25 \mathrm{mg} / \mathrm{kg}$ ). An injection of CPA ( 25 but not $10 \mathrm{mg} / \mathrm{kg}$ ) alone also significantly lowered rectal temperature of rats (Fig. 5).

Results from the second series of experiments indicated that there was also a significant effect on body temperature of rats following treatment of CPA, MDMA, MDMA plus CPA, and saline $[F(3,20)=9.37, P<$ $0.0004]$. Rectal temperature of rats increased after the first injection of MDMA, about $0.80^{\circ} \mathrm{C}$ at 4 and $5 \mathrm{~h}$ postinjection, significantly higher than that of saline control (Fig. 6A). There was no increase in temperature over saline controls after the second injection of MDMA at Hour 7. In contrast, animals treated concurrently with MDMA plus CPA showed significant decreases in rectal temperatures at both $1 \mathrm{~h}$ after the first and the second injection of MDMA plus CPA. The temperatures were significantly lower than those of rats treated with MDMA plus saline at 1 to $4 \mathrm{~h}$ after the second injection of MDMA plus CPA (Fig. 6A). 
TABLE II. Effects of antihistamines on scavenging of hydroxyl radicals

\begin{tabular}{cccccc}
\hline & \multicolumn{5}{c}{ Hydroxyl radicals (Mean \pm SD $)$} \\
\cline { 2 - 6 } $\begin{array}{c}\text { Concentration of } \\
\text { antihistamine }\end{array}$ & $\begin{array}{c}\text { CPA } \\
(\mathrm{n}=4)\end{array}$ & $\begin{array}{c}\text { DIPH } \\
(\mathrm{n}=3)\end{array}$ & $\begin{array}{c}\text { TRIP } \\
(\mathrm{n}=3)\end{array}$ & $\begin{array}{c}\text { PYRI } \\
(\mathrm{n}=3)\end{array}$ & $\begin{array}{c}\text { Maleic acid } \\
(\mathrm{n}=2)\end{array}$ \\
\hline 0 & $100.78 \pm 1.15$ & $100.12 \pm 0.18$ & $100.14 \pm 0.17$ & $100.14 \pm 0.17$ & 100,100 \\
$10 \mathrm{mM}$ & $57.26 \pm 6.07 * *$ & $122.74 \pm 9.66$ & $76.54 \pm 4.68^{* *}$ & $52.45 \pm 6.72^{* *}$ & 113,100 \\
$3.0 \mathrm{mM}$ & $60.72 \pm 6.97 * *$ & $115.56 \pm 6.17$ & $98.59 \pm 1.87$ & $61.26 \pm 13.31 *$ & 120,134 \\
$1.0 \mathrm{mM}$ & $75.23 \pm 10.32 * *$ & $109.85 \pm 11.98$ & $115.16 \pm 1.19 *$ & $83.59 \pm 14.12$ & 121,116 \\
$0.3 \mathrm{mM}$ & $95.57 \pm 6.32$ & $105.26 \pm 5.72$ & $106.34 \pm 5.92$ & $91.75 \pm 6.13$ & 110,123 \\
\hline
\end{tabular}

The hydroxyl radicals generated by the reaction mixture (see text, without antihistamine and maleic acid) measured as the absorbance at $532 \mathrm{~nm}$ was assigned as $100 \%$. Alteration of the absorbance of the solution indicated alteration in formation of hydroxyl radicals. $\mathrm{N}$ indicates the number of experiments with triplicate for each of experiment. $* \mathrm{P}<0.05$.

$* * \mathrm{P}<0.01$ vs. appropriate controls.

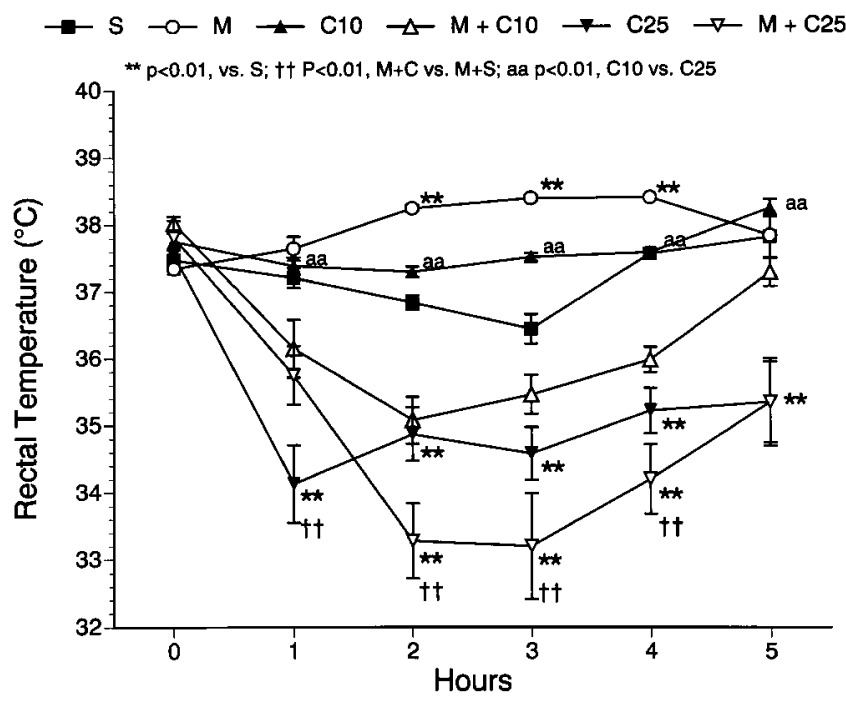

Fig. 5. Effects of CPA (C) on MDMA (M)-induced hyperthermia in rats. $\mathrm{C} 10$ and $\mathrm{C} 25$ indicate the dose of $\mathrm{CPA}, \mathrm{mg} / \mathrm{kg}$. Results are mean \pm SEM.

As compared with both saline controls and those treated with MDMA plus saline, rectal temperatures of animals injected with CPA $3 \mathrm{~h}$ after MDMA significantly decreased at 1-5 h (Hours 4-8) after the first CPA injection and again at 1-3 h (11-13 h) after the second CPA injection ( $3 \mathrm{~h}$ after the second MDMA injection) (data not shown). As compared to saline controls, rectal temperatures of rats injected with CPA $6 \mathrm{~h}$ after MDMA significantly increased at $5 \mathrm{~h}$, and decreased at 1-3 h (Hours 7-9) after the first CPA injection. Rectal temperatures were significantly lower than those treated with MDMA plus saline at 1-6 $\mathrm{h}$ (Hours 7-12) after the second CPA injection (data not shown).

\section{Effects of DIPH, TRIP, and PYRI on MDMA-induced hyperthermia}

There was a significant effect on body temperature of rats following treatment of DIPH, MDMA, and saline, alone or in combination $[F(3,20)=6.39, P<0.0033]$. As compared to the saline controls, rectal temperature of
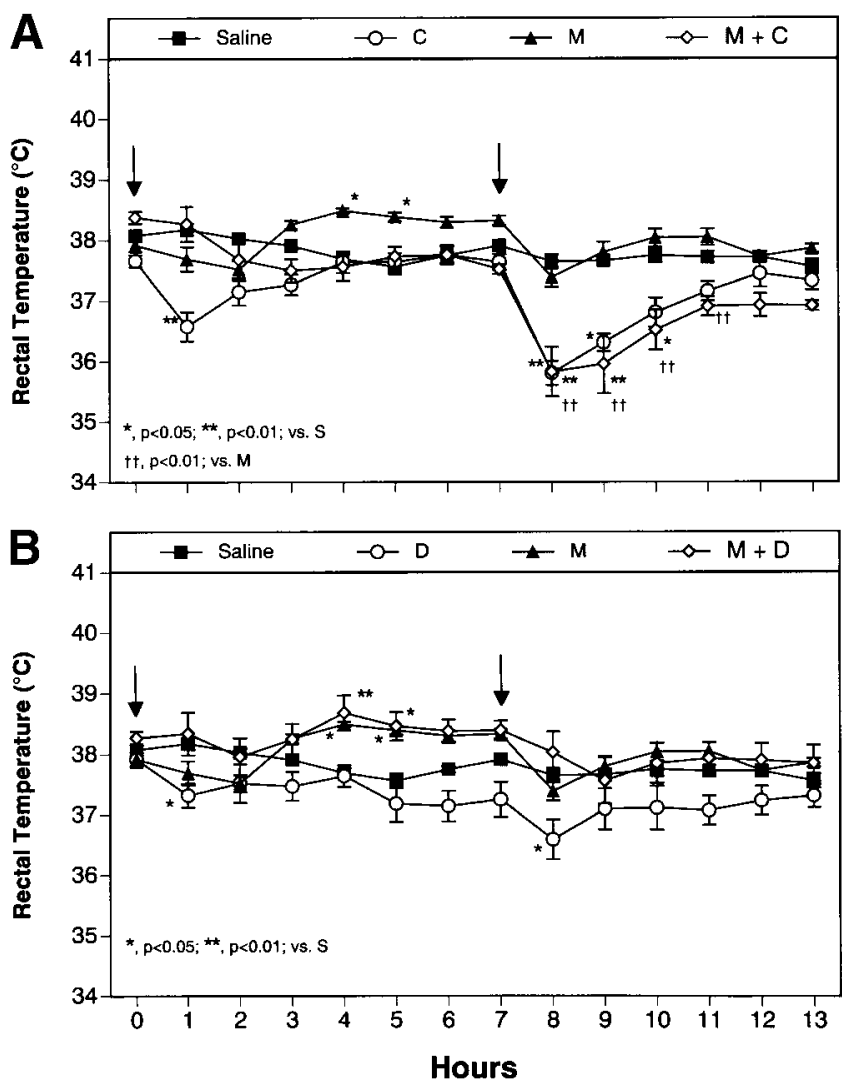

Fig. 6. Effects of chlorpheniramine (A) and diphenhydramine (B) (20 mg/kg, i.p.) on MDMA (20 mg/kg, s.c. twice, $7 \mathrm{~h}$ apart)-induced hyperthermia in rats $(n=6)$. Results are mean \pm SEM.

rats treated with MDMA plus DIPH increased slightly but significantly at 4- and 5-h intervals after the first drug injection. There was no significant alteration of body temperature after the second injection of MDMA plus DIPH. Rectal temperature of DIPH-treated rats decreased at $1 \mathrm{~h}$ after the first or the second injection (i.e., Hour 8) (Fig. 6B).

There was a significant effect on body temperature of rats treated with MDMA, TRIP, and saline, al one and in combination $[F(3,20)=3.70, P<0.031]$. After the first injection of MDMA plus TRIP and as compared to the saline-treated rats, rectal temperature of rats 

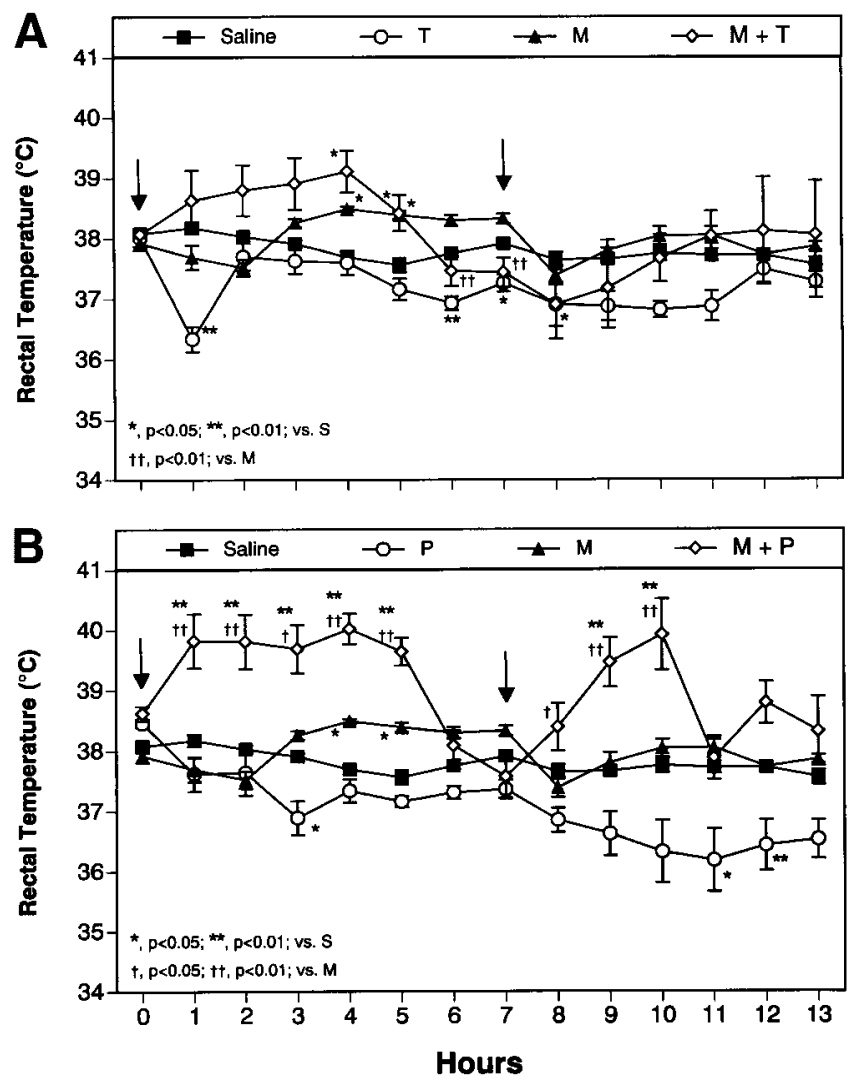

Fig. 7. Effects of tripelennamine (A) and pyrilamine (B) $(20 \mathrm{mg} / \mathrm{kg}$ i.p.) on MDMA (20 mg/kg, s.c. twice, $7 \mathrm{~h}$ apart)-induced hyperthermia in rats $(n=6)$. Results are mean SEM.

treated with MDMA plus TRIP increased from 1-4 $\mathrm{h}$ (significantly higher at $4 \mathrm{~h}$ ) and was significantly decreased at 6 and $7 \mathrm{~h}$. After the second injection of the drugs, two out of six rats showed hyperthermia (above $39^{\circ} \mathrm{C}$ ) at $10 \mathrm{~h}$, which was brought down with crushed ice (Fig. 7A). Rectal temperature of rats decreased significantly at $1 \mathrm{~h}$ after the first injection of TRIP and at 1-3 h (i.e., Hours 8-10) after the second injection of TRIP.

There was a significant effect on body temperature of rats treated with MDMA, PYRI, and saline, alone and in combination $[F(3,20)=33.22, P<0.00001]$. After the first injection of MDMA plus PYRI, rectal temperatures of rats increased significantly to above $39^{\circ} \mathrm{C}$ (five out of six rats) from 1-5-h intervals and again at 1-4 $\mathrm{h}$ (Hours 8-10) after the second injection of MDMA plus PYRI. The temperature was brought down with crushed ice at $10 \mathrm{~h}$ after the second dose of MDMA plus PYRI (Fig. 7B). The rectal temperature of PYRI-treated rats decreased at $3 \mathrm{~h}$ after the first injection and decreased at 4 and $5 \mathrm{~h}$ (i.e., Hours 11 and 12) after the second injection of PYRI .

\section{Interaction of MDMA and antihistamines Interaction of MDMA and CPA}

Three out of four rats died between 1 and $18 \mathrm{~h}$ after a concurrent injection of $40 \mathrm{mg} / \mathrm{kg}$ of MDMA plus 50 $\mathrm{mg} / \mathrm{kg}$ of CPA. Likewise, three out of six rats died between 0.5 and $72 \mathrm{~h}$ after a concurrent injection of 20 $\mathrm{mg} / \mathrm{kg}$ of MDMA plus $50 \mathrm{mg} / \mathrm{kg}$ of CPA. There was no mortality in rats treated with either a dose of $40 \mathrm{mg} / \mathrm{kg}$ of MDMA alone or a dose of $20 \mathrm{mg} / \mathrm{kg}$ of MDMA plus 25 $\mathrm{mg} / \mathrm{kg}$ of CPA and a dose of $50 \mathrm{mg} / \mathrm{kg}$ of CPA alone.

\section{Interaction of MDMA with DIPH, TRIP, and PYRI}

One rat died between 7- and 15-h intervals (i.e., Hours 14 and 22) after the second concurrent injection of MDMA (20 mg/kg) plus DIPH (20 mg/kg). One rat died between 5 and $6 \mathrm{~h}$ after the first injection and one died between 7 and $15 \mathrm{~h}$ (Hours 14 and 22) after the second injection of MDMA (20 mg/kg) plus TRIP (20 $\mathrm{mg} / \mathrm{kg}$ ). Rats sweated profusely, with hyperthermia at 1-5 $\mathrm{h}$ after the first injection of MDMA ( $20 \mathrm{mg} / \mathrm{kg})$ plus PYRI (20 mg/kg). One rat died at $5 \mathrm{~h}$ after the first concurrent injection of MDMA plus PYRI and three died between 7 and $15 \mathrm{~h}$ (Hours 14 and 22) after the second injection of MDMA plus PYRI .

\section{DISCUSSION}

The present results show that CPA attenuated MDMA-induced depletion of serotonin when administered concurrently with MDMA, or 3 and $6 \mathrm{~h}$ after MDMA administration. MDMA-induced depletion was also attenuated by lowering theenvironmental temperature (Broening et al., 1995; Che et al., 1995; Colado et al., 1993; Miller and O'Callaghan, 1994; Yeh, 1999a), by treatment with 5-HT uptake inhibitors, fluoxetine and citalopram (Schmidt, 1987; Fuller et al., 1975), and by CuZn-superoxide dismutase (Cadet et al., 1994, 1995). Release of 5-HT by MDMA, methamphetamine, PCA, and FEN is thought to be through a common mechanism, since it was blocked by fluoxetine and cocaine (Berger et al., 1992). Thus, the mechanism(s) of MDMAinduced neurotoxicity appears to be due to a series of reactions, e.g., release of 5-HT and DA, then transport into 5-HT neurons and oxidation by enzymes of P-450 and monoamine oxidase to 5-hydroxyindoleacetic acid, superoxide anions, and catechol quinones (Kuhn and Arthur, 1998). MDMA is also oxidized to a quinone (Hiramatsu et al., 1990). The superoxide anions and catechol quinones interact with thetryptophan hydroxylase and 5-HT transporters via lipid peroxidation and covalent binding, finally destroying 5-HT neurons.

It is well known that MDMA-induced depletion of 5-HT is temperature-dependent; higher body temperature caused higher decreased of 5-HT (Miller and O'Callaghan, 1994, and references cited above). Increased body temperature probably speeds up the metabolic process, which in turn increases the rate of transport of 5-HT and MDMA into 5-HT neurons and increases in the enzymatic activity of P-450 and monoamine oxidase. The overall result is that these reactions yield more superoxide anions, catechol quinones, and 
the toxic metabolites of MDMA, 3,4-di hydroxymethamphetamine quinoine and 2,4,5-trihydroxymethamphetamine (Tri-OH-MDMA). CPA decreased MDMA-induced hyperthermia. Attenuation of MDMA-induced depletion of 5-HT by CPA probably involves one or all the possible mechanisms mentioned above.

The substituted amphetamines- [e.g. p-chloromethamphetamine (PCMA)-, p-chloroamphetamine (PCA)-, 4-methyl- $\alpha$-ethyl-m-tyramine (MET)- and fenfluramine (FEN)]-induced depletion of 5-HT is attenuated by CPA (Meek et al, 1971; Schmidt 1987; Fuller, et al, 1975; Carlsson and Lindqvist, 1969; Yeh, 1999b). The mechanism(s) of these substituted amphetamine-induced depletion of $5-\mathrm{HT}$ is not clear but may share some mechanism(s) of MDMA-induced depletion of 5-HT.

The present results show that the rank order of protection of the antihistamines against MDMAinduced depletion of 5-HT and 5-HIAA in the brain regions is CPA $>$ DIPH $>$ TRIP, and agree with a report of protection against acute MET-induced depletion of serotonin ( $3 \mathrm{~h}$ ) in mice, and with potencies for CPA ( $85 \%$ of controls) > DIPH (64\%) > TRIP (33\%) (Carlsson and Lindqvist, 1969). It is unlikely that the antihistamines prevent MDMA's neurotoxicity by altering brain 5-HT levels, as they did not alter 5-HT and 5-HIAA levels when given al one, a finding consistent with a previous report (N owak and Zawilska, 1985).

\section{Effects of antihistamines on MDMA-induced depletion of 5-HT and 5-HIAA and alteration of MDMA-induced body temperature}

The present results 1 ) indicate that the effect of the antihistamines on alteration of MDMA-induced hyperthermia correlates well with the effect of the antihistamines on MDMA-induced depletion of 5-HT examined 5 days later, and 2) agree with the finding that MDMAinduced hyperthermia correlates inversely with levels of 5-HT in the brain tissue of mice and rats $3 \mathrm{~h}$ after MDMA (McNamara et al., 1995; Colado et al., 1997). MDMA-induced neurotoxicity can be attenuated by lowering the environmental temperature or by drugs which attenuate MDMA-induced hyperthermia (i.e., dizocilpine, ethanol, pentobarbital, diethyldithiocarbamate, chloral hydrate, d-fenfluramine, and N-t-butyl- $\alpha$ phenylnitrone (PBN)L) (Broening et al., 1995; Che et al., 1995; Colado et al., 1993; Miller and O'Callaghan, 1994; Yeh, 1999a). The mechanism of protection of MDMA-induced neurotoxicity by lowering body temperature could be due to decreases of 5-HT release and formation of superoxide radicals and catechol quinones. Indeed, the lowering of body temperature has been shown to decrease catabolic function, yielding lesser amounts of hydrogen peroxide and hydroxyl radicals in the brain (Chiueh et al., 1994; Kil et al., 1996; Lei et al., 1997). Furthermore, temperature also affects the uptake of $\left[{ }^{3} \mathrm{H}\right] 5-\mathrm{HT}$ into and release of $\left[{ }^{3} \mathrm{H}\right] 5-\mathrm{HT}$ from isolated rabbit platel ets (Cusimano and Sankar, 1977), and the absorption and metabolism of drugs. Higher temperature increases the uptake and release of 5- $\mathrm{HT}$, as well as increased absorption and metabolism of drugs (Kalser et al., 1965; Holtzman and Carr, 1972; Clausing et al., 1998). MDMA-induced neurotoxicity has also been attributed to its metabolites (Elayan et al., 1993) and formation of M DMA metabolites involves superoxide radicals (Hiramatsu et al., 1990). Thus, reduction of body temperature induced by CPA could contribute to the protection of MDMA-induced depletion of 5-HT via decreasing the absorption and metabolism of MDMA, thus yielding lesser amounts of superoxide anions and catechol quinones, of 3,4dihydroxymethamphetaminequinoneand thetoxic metabol ite of MDMA, Tri-OH-MDMA (Elayan et al., 1993).

The decrease in body temperature after treatment with MDMA plus CPA depends on the dose of CPA. The body temperature of rats treated with MDMA plus 25 $\mathrm{mg} / \mathrm{kg}$ of CPA administered concurrently was lower and its duration longer than that of rats treated with MDMA plus $10 \mathrm{mg} / \mathrm{kg}$ of CPA (Fig. 5). The content of 5-HT and 5-HIAA in the brain tissues of rats treated with MDMA plus $25 \mathrm{mg} / \mathrm{kg}$ of CPA appeared higher than that of rats treated with MDMA plus $10 \mathrm{mg} / \mathrm{kg}$ of CPA (F ig. 2). CPA ( $20 \mathrm{mg} / \mathrm{kg}$ ) admi nistered 3 or $6 \mathrm{~h}$ after MDMA also attenuated MDMA-induced hyperthermia and MDMA-induced depletion of 5-HT. A dose of CPA smaller than $10 \mathrm{mg} / \mathrm{kg}$ was not tested because $5 \mathrm{mg} / \mathrm{kg}$ of CPA did not protect FEN-induced depletion of 5-HT (Yeh, 1999b).

A comparison was made of the effect of different antihistamines on MDM A-induced hyperthermia; a 20 $\mathrm{mg} / \mathrm{kg}$ dose of CPA, DI PH, TRIP, and PYRI was used. As compared to MDM A-treated rats, the body temperature of rats treated with MDMA plus CPA $(20 \mathrm{mg} / \mathrm{kg})$ decreased significantly at 1-4-h intervals after the second injection, whereas it showed a downward trend after the first injection. Treatment with MDMA plus DIPH did not result in significant difference from that of rats treated with MDMA after the first and second injection. Treatment with MDMA plus TRIP showed an increasing trend in temperature after the first injection which was significantly higher than that of MDMAtreated rats. The body temperature of some rats was brought down with crushed ice after the second injection. Treatment with MDMA plus PYRI significantly increased the temperature after the first and the second injection and crushed ice brought down this temperature.

There was a correlation between the body temperature of rats and the depletion of 5-HT induced by MDMA plus an antihistamine. These results suggest that temperature plays an important role in theMDMAinduced depletion of 5-HT. It is unclear why MDMA plus different antihistamines yielded different body temperature alterations, but this does not appear to be 
related to the antihistamine's ability to prevent transport into 5-HT neurons.

The effect of time of CPA administration on MDMAinduced depletion of 5-HT observed in the present study is similar to the protection against MDMA- and PCA-induced depletion of serotonin by fluoxetine in rats (Schmidt, 1987) and mice (Fuller et al., 1975). They reported that administration of fluoxetine at $6 \mathrm{~h}$ after MDMA in rats and at 8,16 , and $24 \mathrm{~h}$ after PCA in mice protects against MDMA- and PCA-induced depletion of 5-HT, respectively. Both CPA (Table I) and fluoxetine inhibit 5-HT uptake (references cited above), decrease MDMA-induced hyperthermia (after fluoxetine plus MDMA, the body temperature decreased, but not significantly, from that of rats treated with saline plus MDMA) (Malberg et al., 1996) and attenuate MDMAinduced depletion of serotonin. Thus, it appears that protection of MDMA-induced depletion of 5-HT by CPA and fluoxetine may be through the same mechanisms, i.e., via inhibition of 5-HT uptake and attenuation of MDMA-induced hyperthermia, although fluoxetine is not an antihistamine.

\section{E ffect of antihistamines on uptake of $\left[{ }^{3} \mathrm{H}\right] 5-\mathrm{HT}$ and binding of $\left[{ }^{3} \mathrm{H}\right]$ paroxetine}

The effects of antihistamines on uptake of $\left[{ }^{3} \mathrm{H}\right] 5-\mathrm{HT}$ and binding of $\left[{ }^{3} \mathrm{H}\right]$ paroxetine were studied in vitro to elucidate the different effects of antihistamine on MDMA-induced depletion of 5-HT. The results show that CPA, PYRI, and TRIP, but not DIPH, are potent inhibitors of $\left[{ }^{3} \mathrm{H}\right] 5-\mathrm{HT}$ uptake into synaptosomes of the cerebral cortex and that CPA is potent inhibitor of the binding of $\left[{ }^{3} \mathrm{H}\right]$ paroxetine to the presynaptic $5-\mathrm{HT}$ transporter, in agreement with a report of Cusimano and Sankar (1977). The IC 50 values of CPA, DIPH, TRIP, and PYRI on [ $\left.{ }^{3} \mathrm{H}\right] 5-\mathrm{HT}$ uptake were $89,11,095$, 90, and $141 \mathrm{nM}$, respectively (Table I), which did not correlate with their protection of MDM A-induced depletion of $5 \mathrm{HT}$. DIPH did protect against MDMA-induced depletion of serotonin, although it was a weak inhibitor of 5-HT uptake.

\section{Effect of antihistamines on scavenging of hydroxyl radicals}

Effects of antihistamines on scavenging of hydroxyl radicals were studied in vitro to elucidate the different effects of antihistamine on MDMA-induced depletion of 5-HT. The efficacy of the antihistamines on scavenging of hydroxyl radicals was CPA $=$ PYRI $>$ TRIP $>>>$ DIPH (Table II) and agrees with the report of inhibition of hydroxylation of lidocaine; the rank order was PYRI ( $9 \%$ of control) $>$ CPA $(35 \%)>$ DI PH $(47 \%)$ (Hiroi et al., 1995). Yet the effectiveness of the antihistamines to scavenge hydroxyl radicals did not correlate with their protection against MDMA-induced 5-HT depletion, i.e., CPA $>$ DIPH $>$ TRIP $>>>$ PYRI. DIPH did protect against MDMA-induced depletion of serotonin, although it had no effect on scavenging of hydroxyl radicals (Tables I, II ; Brown and Vernikos, 1980). This discrepancy could be due to the fact that the depletion of $5-\mathrm{HT}$ by MDMA is probably mediated through the superoxide anions and catechol quinones, not hydroxylfree radicals.

The degree of protection against MDMA-induced depletion of 5-HT provided by the antihistamines correlated better with the data on body temperature alteration by MDMA plus the antihistamines rather than with other biochemical parameters. These results suggest that protection against MDMA neurotoxicity by CPA or DIPH may be due to a decrease in body temperature. The effect of antihistamines on absorption and metabolism of MDMA and MDMA-induced stimulatory activity on behavior and the effect of other nonsedative antihistamines on MDMA-induced 5-HT depletion have yet to be examined.

\section{ACKNOWLEDGMENT}

The authors thank Dr. Anand L. Misra for review of the manuscript.

\section{REFERENCES}

Battaglia G, Yeh SY, O'Hearn E, Molliver ME, Kuhar MJ , De Souza E B. 1987. 3,4-M ethylenedioxymethamphetamineand 3,4-methylene dioxyamphetamine destroy serotonin terminals in rat brain: quantification of neurodegeneration by measurement of $\left[{ }^{3} \mathrm{H}\right]$ paroxetine labeled serotonin uptake sites. J Pharmacol Exp Ther 242:911-916.

Berger UV, Gu XF, Azmitia EC. 1992. The substituted amphetamines 3,4-methylenedioxymethamphetamine, methamphetamine, p-chloroamphetamine and fenfluramine induce 5-hydroxytryptamine re lease via a common mechanism blocked by fluoxetine and cocaine. Eur J Pharmacol 215:153-160.

Boja J W, Kuhar MJ , Kopajtic T, Yang E, Abraham P, Lewin AH, Carrol FI. 1995. Secondary amine analogues of 3- $\beta$-(4'-substituted phenyl) tropane-2 $\beta$-carboxylic acid esters and $\mathrm{N}$-norcocaine exhibit enhanced affinity for serotonin and norepinephrine transporters. J Med Chem 37:1220-1230.

Broening HW, Bowyer J F, Slikker W J r. 1995. Age-dependent sensitivity of rats to long-term effects of the serotonergic neurotoxicant ( \pm )-3,4-methylenedioxymethylamphetamine (MDMA) correlates with the magnitude of the MDMA-induced thermal response. J Pharmacol Exp Ther 275:325-333.

Brown PA, Vernikos J . 1980. Antihistamines effect on synaptosomal uptake of serotonin, norepinephrine and dopamine. Eur J Pharmacol 65:89-92.

Cadet J L, Ladenheim B, Baum I, Carlson E, Epstein C. 1994 CuZn-superoxide dismutase (CuZnSOD) transgenic mice show resistance to the lethal effects of methylenedioxyamphetamine (MDA) and of methylenedioxymethamphetamine (MDMA). Brain Res 655: 259-262.

Cadet J L, Ladenheim B, Hirata H, Rothman RB, Ali S, Carlson E, Epstein C. 1995. Superoxide radicals mediate the biochemical effects of methylenedi oxymethamphetamine(MDMA): evidence from using CuZn-superoxide dismutase transgenicmice. Synapse 21:169176.

Carlsson A, Lindqvist M. 1969. Central and peripheral monoaminergic membrane-pump blockade by some addictive analgesics and antihistamines. J Pharm Pharmacol 21:460-464.

Che S, J ohnson M, Hanson GR, Gibb J W. 1995. Body temperature effect on methylenedioxymethamphetamine-induced acute decrease in tryptophan hydroxylase activity. Eur J Pharmacol 293:447-453.

Chiueh CC, Wu R-M, Mohanakumar KP, Sternberger LM, Frishna T, Obata T, Murphy DL. 1994. In vivo generation of hydroxyl radicals and MPTP-induced dopaminergic toxicity in the basal ganglia. In the neurobiology of NO• and $\bullet \mathrm{OH}$. Ann NY Acad Sci 738:15-25.

Clausing P, Newport GD, Bowyer J F. 1998. Fenfluramine and norfenfluramine levels in brain microdialysate, brain tissue and plasma of 
rats administered doses of d-fenfluramine known to deplete 5-hydroxytryptamine levels in brain. J Pharmacol Exp Ther 284:618624.

Colado MI, Murray TK, Green AR. 1993. 5-HT loss in rat brain following 3,4-methylenedioxymethamphetamine (MDMA), p-chloroamphetamine and fenfluramine administration and effects of chlormethiazole and dizocil pine. Br J Pharmacol 108:583-589.

Colado MI, O'Shea E, Granados R, Murray TK, Green AR. 1997. In vivo evidence for free radical involvement in the degeneration of rat brain 5-HT following administration of MDMA ("ecstasy") and p-chloroamphetamine but not the degeneration following fenfluramine. Br J Pharmacol 121:889-900.

Commins DL, Vosmer G, Virus RM, Woolverton WL, Schuster ER, Seiden LS. 1987. Biochemical and histological evidence that methylenedioxymethamphetamine (MDMA) is toxic to neurons in the rat brain. J Pharmacol Exp Ther 241:338-345.

CusimanoV J, Sankar DVS. 1977. U ptake and release of 5-hydroxytryptamine by rabbit platelets. II. Kinetic analysis of inhibition by chlorpheniramine maleate. Biochem Med 17:267-274.

Dixon WJ, Brown MB, Engelman L, J ennrich RL. 1990. BMDP statistical software manual. Berkeley: University of California Press.

Elayan I, Gibb J W, Hanson GR, Lim HK, Foltz RL, J ohnson M. 1993. Long-term alteration in the central monoaminergic systems of the rat by 2,4,5-trihydroxyamphetamine, 2,4,5-trihydroxymethamphetamine and 3,4-dihydroxymethamphetamine on central tryptophan hydroxylase activity. J Pharmacol Exp Ther 265:813-817.

Farfel GM, Seiden LS. 1995. Role of hypothermia in the mechanism of protection against serotonergic toxicity. I. Experiments using 3,4 methylenedioxymethamphetamine, dizocilpine, CGS 19755 and NBQX.J Pharmacol Exp Ther 272:860-867.

Fuller RW, Snoddy HD, Molly BB. 1975. Blockade of amine depletion by nisoxetine in comparison to other uptake inhibitors. Psychopharmacol Commun 1:455-464.

Glowinski J , I versen LL. 1966. Regional studies of catecholamines in rat brain. I. The disposition of $\left[{ }^{3} \mathrm{H}\right]$-norepinephrine, $\left[{ }^{3} \mathrm{H}\right]$-dopamine, and $\left[{ }^{3} \mathrm{H}\right]$-DOPA in various regions of the brain. J Neurochem 13:655-659.

Hardman HF, Haavik CO, Seevers MH. 1973. Relationship of the structure of mescaline and seven analogs to toxicity and behavior in five species of Iaboratory animals. Toxicol Appl Pharmacol 25:299309.

Henry J A, J effreys KJ , Dawling S. 1992. Toxicity and deaths from 3,4-methylenedioxymethamphetamine ("ecstasy"). Lancet 340:384387.

Hiramatsu M, Kumagai Y, Unger SE, Cho AK. 1990. Metabolism of methylenedioxymethamphetamine: formation of dihydroxymethamphetamine and a quinone identified as its glutathione adduct. J Pharmacol Exp Ther 254:521-527.

Hiroi T, Ohishi N, Imaoka S, Yabusaki Y, Fukui H, Funae Y. 1995. Mepyramine, a histamine $\mathrm{HI}$ receptor antagonist, inhibits the metabolic activity of rats and human P4502D forms. J Pharmacol Exp Ther 272:939-944.

Holtzman J L, Carr ML. 1972. The temperature dependence of the components of the hepatic microsomal mixed-function oxidases. Arch Biochem Biophys 150:227-234.

Insel TR, Battaglia G, J ohannessen J N, Marra S, De Souza EB. 1989. 3,4-Methylenenedioxymethamphetamine ("E cstasy") selectively destroys brain serotonin terminals in rhesus monkeys. J Pharmacol Exp Ther 249:713-720.

Kalser SC, Kelvington EJ, Randolph MM, Santonmenna DM. 1965. Drug metabolism in hypothermia. II. C14 atropine uptake, metabolism and excretion by the isolated perfused rat liver. J Pharmacol Exp Ther 147:260-269.
Kil YH, Zhang J, Piantadosi CA. 1996. Brain temperature alters hydroxyl radical production during cerebral ischemia/reperfusion in rats. J Cerebral Blood Metab 16:100-106.

Kuhn DM, Arthur R J r. 1998. Dopamine inactivates tryptophan hydroxylase and forms a redox-cycling quinoprotein: possibleendogenous toxin to serotonin neurons. J Neurosci 15:7111-7117.

Lei $B$, Adachi N, Arai T. 1997. The effect of hypothermia on $\mathrm{H}_{2} \mathrm{O}_{2}$ production during ischemia and reperfusion: a microdialysis study in the gerbil hippocampus. Neurosci Lett 222:91-94.

Lowry OH, Roserbrough NJ, Farr AL, Randall RJ . 1951. Protein measurement with the Folin phenol reagent. J Biol Chem 193:265275.

Malberg J E, Sabot KE, Seiden LS. 1996. Coadministration of MDMA with drugs that protect against MDMA neurotoxicity produces different effects on body temperature in the rat. J Pharmacol Exp Ther 278:258-267.

McNamara MG, Kelly J P, Leonard BE. 1995. The effect of acute MDMA administration on body temperature, serum corticosterone and neurotransmitter concentrations in male and female rats. Human Psychopharmacol 10:373-383.

McPherson GA. 1988. Kinetic, EBDA, Ligand, Lowry: a collection of radioligand binding analysis programs. Amsterdam: Elsevier.

Meek J L, Fuxe K, Carlsson A. 1971. Blockade of p-chloromethamphetamine induced 5-hydroxytryptamine depletion by chlorimipramine, chlorpheniramine and meperidine. Biochem Pharmacol 20:707-709.

Miller DB, O'Callaghan J P. 1994. Environment-, drug- and stressinduced alterations in body temperature affect the neurotoxicity of substituted amphetamines in the C57BL/6J mouse. J Pharmacol Exp Ther 270:752-760.

Nash KF J r, Meltzer HY, Gudelsky GA. 1988. Elevation of serum prolactin and cortisone concentrations in the rat after the administration of 3,4-methylenedioxymethamphetamine. J Pharmacol Exp Ther 245:873-879.

Nowak J Z, Zawilska J . 1985. Histamine in the rat brain: effect of acute and chronic treatment with tricyclic antidepressants and $\mathrm{H}^{1-}$ antihistamines. Pol J Pharmacol Pharm 37:147-162.

Rehman A, Whiteman M, Halliwell B. 1997. Scavenging of hydroxyl radicals but not peroxynitrite by inhibitors and substrates of nitric oxide syntheses. BrJ Pharmacol 122:1072-1705.

Rothman RB, Lewis B, Dersch C, Xu H, Radesca L, de Costa BR, Rice KC, Kilburn RB, Akunne HC, Pert A. 1993. Identification of a GBR12935 homolog, LR1111, which is over 4,000-fold selective for dopamine transporter, relative to serotonin and norepinephrine transporters. Synapse 14:34-39.

Schmidt CJ . 1987. Neurotoxicity of the psychedelic amphetamine, methylenedioxymethamphetamine. J Pharmacol Exp Ther 240:1-7.

Stone DM, Stahl DC, Hanson GR, Gibb J W. 1986. The effects of 3,4-methylenedioxymethamphetamine (MDMA) and 3,4-methylenedioxyamphetamine (MDA) on monoaminergic systems in the rat brain. Eur J Pharmacol 128:41-48.

Yeh SY. 1997a. The effect of salicylate on 3,4-methylenedioxymethamphetamine (MDMA)-induced neurotoxicity in rats. Pharmacol Biochem Behav 58:701-708.

Yeh SY. 1997b. Chlorpheniramine protects against 3,4-methylenedioxymethamphetamine-induced depletion of serotonin in rats. Neurosci Abstr 27:21-41.

Yeh SY. 1999a. N-tert-butyl-al pha-phenylnitrone protects against 3,4-methylenedioxymethamphetamine-induced depletion of serotonin in rats. Synapse 31:169-177.

Yeh, SY. 1999b. Effects of antihistamines on fenfluramiine-induced depletion of indoles in the brain of rats. Synapse, 32:301-311. 